\title{
Migrant Child Labour of Western Odisha in India: An Analytical Study
}

\author{
Samir Kumar Nanda ${ }^{1}$ \\ ${ }^{1}$ Ph.D. (Sociology), Programme Manager-cum-Inspector, National Child Labour Project (Ministry of \\ Labour \& Employment, Govt. of India), Matha Sahi, PO/Dist-DEOGARH, Odisha-768108,India
}

\begin{tabular}{|c|c|}
\hline Arti & Abstract \\
\hline $\begin{array}{l}\text { Article history: } \\
\text { Received: } 18 \text { September } 2020 \\
\text { Revised: } 27 \text { October } 2020 \\
\text { Accepted: } 28 \text { October } 2020\end{array}$ & $\begin{array}{l}\text { Purpose: The aim of this study is to analyze the status of migrant child } \\
\text { laborers in all the ten districts of Western Odisha in India. Identification of } \\
\text { the area of concentration of migrant child labor in Western Odisha and } \\
\text { evaluations of dimensions of the problem has been made in this article. } \\
\text { Approach/Methodology/Design: In this study descriptive qualitative }\end{array}$ \\
\hline $\begin{array}{l}\text { Keywords: } \\
\text { Migration, } \\
\text { Child Labour, } \\
\text { Western Odisha, } \\
\text { Nuakhai Festival }\end{array}$ & $\begin{array}{l}\text { research method is applied. The population of the research was the innocent } \\
\text { migrant child laborers and their parents of Western Odisha.Total sampling } \\
\text { technique was used in this study. The sample consisted of eighty migrant } \\
\text { child laborers that had migrated to Andhra Pradesh and were rescued by } \\
\text { the author with the help of Labor \& Employment Department, Government } \\
\text { of Odisha, Government of Andhra Pradesh, and Andhra Pradesh Police. }\end{array}$ \\
\hline $\begin{array}{l}\text { Paper Type : } \\
\text { Research Article }\end{array}$ & $\begin{array}{l}\text { Findings: The result of the study indicates that due to acute poverty, } \\
\text { illiteracy of children and their parents, low family income and big family } \\
\text { size, people have migrated from one state to another state with their family }\end{array}$ \\
\hline Corresponding Author: & $\begin{array}{l}\text { members and children in search of works and higher wages. It is also found } \\
\text { out that children are forced to work in hazardous occupations like brick }\end{array}$ \\
\hline Samir Kumar Nanda & $\begin{array}{l}\text { kilns instead of going to schools. Moreover, it can be stated that the lack of } \\
\text { awareness and non-implementation of Labour Laws are also among the } \\
\text { main reasons for the prevalence of child labour. }\end{array}$ \\
\hline $\begin{array}{l}\text { Email: } \\
\text { drsamir.2015@gmail.com }\end{array}$ & $\begin{array}{l}\text { Practical Implications: The research study contributes to the understanding } \\
\text { of the causes, consequences and remedies of child labor problems in the }\end{array}$ \\
\hline $\begin{array}{l}\text { ORCID ID: } \\
\text { https://orcid.org/0000-0002- } \\
\text { 8391-3360 }\end{array}$ & $\begin{array}{l}\text { society. The results will provide solutions to the stakeholders to integrate the } \\
\text { victims of child labor for the betterment of their lives. } \\
\text { Originality/value: The study explores the impact of the child labor system } \\
\text { on the society. Certain possible solutions are suggested to make Western } \\
\text { Odisha, Odisha as well as the whole country, free from child labor } \\
\text { practices. }\end{array}$ \\
\hline
\end{tabular}

\section{Introduction}

Mobility is an integral part of human existence (De Haas \& Rodríguez, 2010). However, all types of human mobility are not migration. In addition to political, social, personal and natural reasons, the socio-economic conditions are also found to be a major cause of migration. Due to the lack of employment opportunities in the villages and home towns, the middleman motivates people to shift their working place to other areas in the hope of finding better wages and employment facilities (Piesse, 2014). Apart from such type of migration, some people shift their residence to elsewhere for seasonal employment or work.

Western Odisha which was known as Dakshin Kosala Kingdom prior to the $5^{\text {th }}$ Century A.D comprises the vast geographical and culturally homogeneous area of India. If we go through the life style, we see a great degree of cultural uniformity which extends from Sundargarh 
district in the northwest to Kalahandi district in the south. The whole Western Odisha includes ten districts of Odisha State namely Balangir, Bargarh, Boudh, Deogarh, Jharsuguda, Kalahandi, Nuapara, Sambalpur,Sonepur \& Sundargarh districts (Nanda, 2019). This region was abundant with gems and jungles, but nowadays Western Odisha is suffering from repeated droughts. This region is considered the poorest region in India.

Despite its vast natural and human resources and the substantial progress achieved during the past 60 years of development plan, Western Odisha continues to be one of the less developed regions with nearly $79 \%$ of its population depending on agriculture and nearly $48 \%$ living below the poverty line (Nanda, 2018). Thereby, the challenge before planning department is to devise programmes to transform a relatively underdeveloped economy characterized by high incidence of poverty and unemployment, low-per capita income, inadequate exploitation of abundant natural resources and inadequate development of socio-economic infrastructure into a vibrant economy on the path to self-sustaining economic growth with equity.

It is estimated that $24.83 \%$ of the total population of Odisha state resides in Western Odisha. Out of which $40 \%$ are Tribal population. Around $10 \%$ of the population belong to Agharia community that migrated from north-western Uttar Pradesh. It is found that around $23.38 \%$ of Scheduled Castes and 33.9\% Scheduled Tribes population of Odisha are residing in this region. This area has $29.75 \%$ of economically backward people of the total population of the

state, $25.8 \%$ are cultivators, $27.52 \%$ are agricultural labourers, $32.18 \%$ are house-hold industrial worker, $25.36 \%$ are workers, $30.54 \%$ are marginal workers and $22.87 \%$ are nonworkers of the state of Odisha. Hence, this study is an attempt to provide an analysis of the current situation of child labour in Odisha in the hope that the findings would be of use to the concerned authorities.

\section{Literature Review}

Nanda, S. K. (2018) has indicated in his study that in Odisha the coastal districts with long coast line have regularly been affected by natural calamities while the districts of Western Odisha are drought-prone areas. As $60 \%$ of the population of Odisha is under BPL Category, therefore, due to poverty, child labour is engaged in various types of hazardous and nonhazardous sectors (Nanda, 2018). In their study "Household Food Insecurity and Child Labour: Some Evidences from Rural Odisha", Raj \& Satpathy (2002) have revealed the same causes of child labour in Western Odisha. According to them social and economic backwardness determine the degree of food insecurity of households (Raj \& Satpathy 2002). The greater the intensity of this insecurity, the more the children would be forced to join work, even though it is a first option for only one-fifth of the households. Analysis of household consumption expenditure shows that the standard of living of the households is higher in Bargarh and Sambalpur districts compared to Bolangir district. Further, the highest proportion of child labour was concentrated in households that fall in the lowest MPCE classes. Lastly, it was established beyond reasonable doubt that, though household food insecurity is a necessary condition for child labour, it is by no means a sufficient one. For a higher incidence of child labour, other factors like relative levels of development of a district 
and existence of demand for labour, among others have to coexist simultaneously vis-à-vis household food security.

\section{Methodology and Procedures}

It is an empirical-analytical study. To make a review of related literatures, books and journals were referred. For collection of data in a systematic manner, a questionnaire was prepared. With the help of a questionnaire and the interview schedule, data were collected from the sample districts of Western Odisha. The author spent some time in the area in different times of the year and freely mixed with the parents of the child labours and established good rapport with them. He was allowed to collect all relevant information about the parents and child labours. He also collected valuable data from the Sate Labour Department Officials, National Child Labour Project (NCLPs) and other related departments working in the area. The Instructors of NCLP schools, village level workers and the workers of NGOs have also supplemented a lot of information regarding the socio-economic life of the child labours and their parents. Having classified and analyzed the field data, the researcher tried to draw logical inferences and make some suggestions for the rehabilitation and elimination of child labour system in Western Odisha, India.

\section{Results and Discussion}

\section{Migration}

Every year after the monsoon, thousands of labourers from Bargarh, Bolangir, Kalahandi, Nuapada, Sonepur and other districts of Western Odisha migrate to Tamilnadu, Kerala, Andhra Pradesh, and Karnatak with their families and children in search of better wages and employments through the Sardar (middleman).Hence, the Kalahandi-Bolangir-Koraput $(\mathrm{KBK})$ region of Western Odisha is usually referred to in negative terms.

\section{Nuakhai Festival}

It is considered one of the major factors that create situations for child labour. To celebrate this festival poor families borrow money in advance from the labour contractors. Soon after the festival, the families migrate in groups to repay the advance money by offering labour to the money lender contractors. They live on the worksites in very unhealthy pathetic conditions. In such case, women and children are subjected to several types of abuses.

\section{Child Worker}

Until a few years ago, migrant parents took their children along because there was no one to take care of them in the village or because of the pathuria system. Under the pathuria system, labour agents would advance money for so-called units, consisting of a couple and one or two children. The children would flip semi-dried bricks or make balls of mud to be moulded at the kilns. 
In Balangir, the district administration rescued 20 children engaged at a brick kiln in Hyderabad in the year 2018. As per reports, the children had accompanied their parents who migrated to Andhra Pradesh in search of work. The children were held captive by a labour agent in inhuman conditions while their parents were working. It is found out that about 0.15 millions of mostly semi-skilled people have migrated from Bolangir district to other states for work during this period out of which 35 percent are children of which 22 per cent are within the age group of 6-14 years,

Table 1: Magnitude of Child Labour (Western Odisha, Odisha \& India)

\begin{tabular}{rccc}
\hline Census Year & Western Odisha & Odisha & India \\
2011 & 75,440 & 92,087 & $43,53,247$ \\
2001 & $1,09,276$ & $3,77,594$ & $1,25,91,667$ \\
1991 & $1,39,526$ & $4,52,394$ & $1,12,85,349$ \\
1981 & $2,70,112$ & $7,02,293$ & $1,36,40,870$ \\
1971 & $1,89,414$ & $4,92,477$ & $1,07,53,985$ \\
\hline
\end{tabular}

Source: Author

We can see the number of child labours identified during the decadal census conducted in the year 1971, 1981, 1991, 2001 \& 2011in Western Odisha, Odisha State and India. When comparing the above statistics, we find that Maximum number of child labours is identified in 1981 census. If we go through the census report of 2011, we observe that the number of child labour has decreased during 2011 census.

Table2: Magnitude of Child Labour of Western Odisha

\begin{tabular}{cccccccc}
\hline $\begin{array}{c}\text { Year of } \\
\text { Survey }\end{array}$ & 1971 & 1981 & 1991 & 1997 & 2001 & 2005 & 2011 \\
$\begin{array}{c}\text { All the ten } \\
\text { districts of }\end{array}$ & 189414 & 270112 & 139526 & 58131 & 109276 & 149299 & 75440 \\
$\begin{array}{c}\text { Western Odisha } \\
\text { Trend }\end{array}$ & & & & & & & \\
\hline
\end{tabular}

Source: Author

During the District Level Child Labour Survey conducted by the National Child Labour Project in the year 1997 and 2005 and during the decadal census held in the years $1997,1981,1991,2001 \& 2011$, the table above shows the numbers of child labour that have been identified in the Western Odisha. If we study the trend of the above figures, we can see that the percentage of child labour decreased to $48 \%$ in the year 1991 in comparison to 1981, $58 \%$ in 1997 survey in comparison to 1991 census and $49 \%$ in the 2011 census in comparison to 2005 survey. But during the rest of the survey period, there is an increasing trend. In the 1981 census percentage increased up to $42 \%$ than in 1971, in 2001 census the figure again increased to $88 \%$ than 1997 survey and in 2005 survey it has been increased $37 \%$ in comparison to 2001 census.

\section{Opinion survey of child labours (migrant sectors) of Raipali and Rengali Village}


The author contacted around 80 numbers of child labours of Raipali and Rengali villages under Sonapur Block in Subarnapur district who had migrated to Andhra Pradesh with parents to get better wages in two brick kilns situated at Konkadivaram village of Gurugubilli Block and Paradhi in Bobbili Mandal in Vizianagaram districts of Andhra Pradesh. These child labourers were rescued by the Labour Department and the researcher interviewed them. The data obtained from them is analyzed below.

A comparative analysis has been made with the opinions of 80 migrated child labours as it follows:

Table 3: Education Status of the Father and Mother of Migrant Child Labours

\begin{tabular}{cccccc}
\hline $\begin{array}{c}\text { Education of } \\
\text { father }\end{array}$ & $\begin{array}{c}\text { No. of } \\
\text { children }\end{array}$ & Percentage & $\begin{array}{c}\text { Education of } \\
\text { mother }\end{array}$ & $\begin{array}{c}\text { No. of } \\
\text { children }\end{array}$ & Percentage \\
Yes & 10 & $12.5 \%$ & Yes & 02 & $2.5 \%$ \\
No & 70 & $87.5 \%$ & No & 78 & $97.5 \%$ \\
Total & 80 & $100 \%$ & Total & 80 & $100 \%$ \\
\hline
\end{tabular}

Source: Author

From the table above, it is clear that only $12.5 \%$ of respondent child labour's fathers and $2.5 \%$ of respondent child labour's mothers are literate. So, illiteracy may be an important reason for which parents cannot realise the consequences of sending their children to work.

To find out the educational status of the parents of 80 numbers of migrant child labours the following table is made with the opinions of 80 numbers of child labours.

Table 4: Education Level of Parents of Migrant Child Labours

\begin{tabular}{|c|c|c|c|c|}
\hline \multirow[t]{2}{*}{ Level of Education } & \multicolumn{2}{|c|}{ Parent } & \multirow[t]{2}{*}{ Total } & \multirow[t]{2}{*}{ Percentage } \\
\hline & Father & Mother & & \\
\hline Up to middle standard & 10 & 2 & 12 & $15 \%$ \\
\hline Up to 10 th Standard & Nil & Nil & Nil & Nil \\
\hline Below 10th Standard & Nil & Nil & Nil & Nil \\
\hline
\end{tabular}

\section{Source: Author}

From this table, it is observed that $15 \%$ of the parents of child labours studied up to middle standard only. To find out the educational level of the migrant child labours, the following table is made based on the survey administered to the 80 child labours.

Table: 5 Education Level of Child Labour in Migrant Sectors

\begin{tabular}{ccc}
\hline Education Level & No. of Child Labour & Percentage \\
Nil & 60 & $75 \%$ \\
I & 7 & $8.75 \%$ \\
II & 10 & $12.5 \%$ \\
III & 3 & $3.75 \%$ \\
\hline
\end{tabular}




\begin{tabular}{ccc}
\hline IV & 0 & 0 \\
V & 0 & 0 \\
Total & 80 & $100 \%$ \\
\hline
\end{tabular}

Source: Author

As shown in this table, we can see that $75 \%$ of child labours have not attended school, $3.75 \%$ have studied up to Class III and $12.5 \%$ have studied up to Class-II and rest are within class I. In order to get the statistics regarding mode and amount of payment of wages, 80 of migrated child labours were interviewed and the result is placed herewith.

Table: 6 Distribution of working children by the mode and amount of payment of wages of

\begin{tabular}{ccc}
\multicolumn{2}{c}{ migrant child labours } \\
\hline Amount of wages/Kind & Number & Percentage \\
$0-50$ & 0 & 0 \\
$51-100$ & 0 & 0 \\
$101 \&$ more & 0 & 0 \\
No money, only food & 80 & $100 \%$ \\
No fixed income & 0 & 0 \\
Total & 80 & $100 \%$ \\
\hline
\end{tabular}

Source: Author

From this table, we can see that all the child labours have worked without any wages. They only get food for work. To find out the occupations of the head of the family of migrated child labours, 80 numbers of migrated child labours were interviewed by the researcher. The opinions of the child labours are placed in a tabular manner below.

Table 7: The Occupation of the Head of the Family of Migrated Child Labours

\begin{tabular}{ccc}
\hline Occupation & No. of Child labour & Percentage \\
Govt. Servant & 0 & 0 \\
Daily Labour \& Agricultural Labour & 25 & $31.25 \%$ \\
Family Tradition \& Farming & 0 & 0 \\
Fishing & 0 & 0 \\
Brick Kilns & 45 & $56.25 \%$ \\
Forest Products \& Seasonal Labour & 10 & $12.5 \%$ \\
Father expired & 0 & 0 \\
Without Work/Drunker/In Jail & 0 & 0 \\
Total & 80 & $100 \%$ \\
\hline
\end{tabular}

Source: Author

If we look into the families of the child labour, we will find that head of family of $31.25 \%$ child labours are working as daily labour and agricultural labour. Again, 56.25\% household heads are engaged in brick kilns. It is clear that the majority of child labours belong to labour 
class. To find out the family income and composition, the participants of this study were interviewed $\&$ the result is placed below.

Table 8: Family Income \& Composition of the Child Labour Family of Migrant Child Labour

\begin{tabular}{cccccc}
\hline \multicolumn{2}{c}{ Family Income /month } & \multicolumn{3}{c}{ Family composition } \\
Family income & $\begin{array}{c}\text { Numbers of } \\
\text { monthly(In Rs.) }\end{array}$ & Percentage & No. of members & $\begin{array}{c}\text { No. of } \\
\text { families }\end{array}$ & Percentage \\
Below 500 & 5 & $6.25 \%$ & $1-2$ & 0 & 0 \\
$501-1000$ & 32 & $40 \%$ & $3-4$ & 17 & $21.25 \%$ \\
$1001-1500$ & 41 & 51.25 & $5-6$ & 53 & $66.25 \%$ \\
$1501-$ more & 2 & $2.5 \%$ & $7-8$ & 10 & $12,5 \%$ \\
No income & 0 & 0 & 8 \& above & 0 & 0 \\
Total & 80 & $100 \%$ & Total & 80 & $100 \%$ \\
\hline
\end{tabular}

Source: Author

This table shows that out of 80 child labours interviewed about $66.25 \%$ families of child labours have 5-6 family members, $12.5 \%$ cases have $7-8$ no. of members, $21.25 \%$ cases have 3-4 family members. Accordingly, it is observed that $78.75 \%$ child labours have more than 5 family members. If we take the case of monthly income of the families of the child labours, we see that $51.25 \%$ household cases have monthly income of Rs.1001/- to Rs1500/-, 40\% have 501/- to 1000/- . The monthly income of $6.25 \%$ families have below Rs500/- whereas only $2.5 \%$ families of child labour have monthly income Rs.1501/- and more. So, the conditions of these people are clearly visible.

There are many reasons of child labour problem. To get an idea about these reasons, the participants of the study were interviewed and their responses are presented in a tabular form below.

Table 9: Reasons of the Child Labour Problems in Migrant Sectors

\begin{tabular}{ccc}
\hline Reasons & $\begin{array}{c}\text { Number of Child } \\
\text { Labour }\end{array}$ & Percentage \\
Poverty/Want of money & 9 & $11.25 \%$ \\
$\begin{array}{c}\text { Parents not want to send } \\
\text { school/Alcoholism }\end{array}$ & 0 & 0 \\
$\begin{array}{c}\text { School problems/No } \\
\text { school/Afraid of teacher }\end{array}$ & 0 & 0 \\
$\begin{array}{c}\text { Family problems } \\
\text { Accompanied with parents } \\
\text { for money }\end{array}$ & 5 & $6.25 \%$ \\
Total & 66 & $82.5 \%$ \\
\hline
\end{tabular}




\section{Source: Author}

If we look into the table, we see that $82.5 \%$ child labours disclosed that they accompany their parents for money. Similarly, $11.25 \%$ of child labour has opined that they joined work for poverty and want of money. Again, $6.25 \%$ child labour has stated that they joined work due to problems in the family.

From the tables above, it is concluded that due to acute poverty people migrate from one state to another state with family members and children. It is also found that children are forced to work in hazardous occupations like brick kilns instead of going to schools. Moreover, it can be stated that the lack of awareness and non-implementation of Labour Laws are also among main reasons for the prevalence of child labour.

\section{Opinion Survey of Govt. Officials}

There are ten districts in Western Odisha. The Labour Department of State Government and National Child Labour Project (NCLP) Offices of Labour and Employment Department, Govt. of India are functioning in Western Odisha as follows:

1. Deputy Labour Commissioner: Sambalpur, Rourkela

2. Assistant Labour Commissioner: Bhawanipatna, Sambalpur, Rourkela, Jharsuguda

3. District Labour Officer: - One in each District

4. Project Director, NCLP Office: In six districts District Labour Officers are in charge of Project Director, and in rest three districts Officers of other departments are in charge of NCLP. In Boudha district NCLP office has not been opened.

In order to get some practical information regarding the causes, consequences and remedial measures of child labour system in Western Odisha, the author interviewed the Officers of State Labour Department and Project Directors, NCLP of nine districts using a questionnaire and the opinions of the Officers are presented below in a tabular form.

Table 10: Common Opinions of the Officials Working In Labour Department \& NCLP in Western Odisha

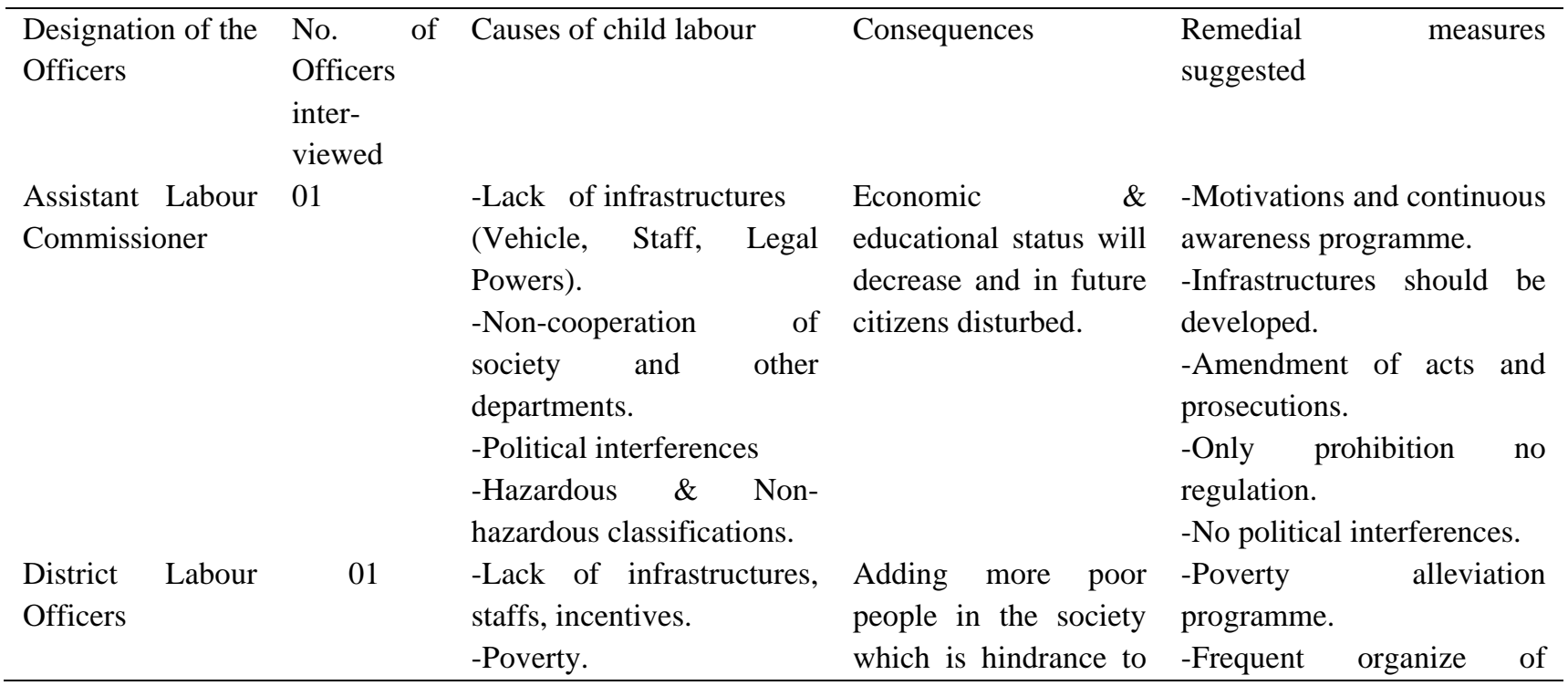




\begin{tabular}{|c|c|c|c|c|}
\hline & & $\begin{array}{l}\text {-Non cooperation of other } \\
\text { departments, child labour } \\
\text { and parents. } \\
\text {-Lack of awareness. } \\
\text {-Illiteracy. } \\
\text {-Non implementation of } \\
\text { acts properly. }\end{array}$ & $\begin{array}{l}\text { the economic } \\
\text { prosperity } \& \\
\text { development of the } \\
\text { nation. }\end{array}$ & $\begin{array}{l}\text { awareness programme. } \\
\text {-Proper implementation of } \\
\text { labour laws. } \\
\text {-Proper administration by } \\
\text { the task force officials. }\end{array}$ \\
\hline $\begin{array}{l}\text { District Labour } \\
\text { Officers \& Project } \\
\text { Directors, NCLP }\end{array}$ & 05 & $\begin{array}{l}\text {-Poverty } \\
\text {-Orphan Child \& } \\
\text { Prostitution. } \\
\text {-Growth } \\
\text { population/generation. } \\
\text {-Illiteracy } \\
\text {-Drought } \\
\text {-Less industry. }\end{array}$ & $\begin{array}{l}\text {-Child only become a } \\
\text { labour instead of } \\
\text { employer and suppress } \\
\text { by the society and } \\
\text { family. } \\
\text {-Educational } \\
\text { deprivations } \\
\text {-Biological growth of } \\
\text { child hampered. }\end{array}$ & $\begin{array}{l}\text {-Self-consciousness among } \\
\text { people, parents \& society. } \\
\text {-Poverty alleviation } \\
\text { programme. } \\
\text {-Increasing literacy rate. } \\
\text {-Awareness progarmme. }\end{array}$ \\
\hline $\begin{array}{l}\text { Project Directors, } \\
\text { NCLP }\end{array}$ & 05 & $\begin{array}{l}\text {-Poverty. } \\
\text {-Lack of awareness } \\
\text {-Illiteracy } \\
\text {-Family traditions }\end{array}$ & $\begin{array}{l}\text {-Bad economic } \\
\text { conditions. } \\
\text {-Bad impact on } \\
\text { society. } \\
\text {-Retarded children } \\
\text { growth. }\end{array}$ & $\begin{array}{l}\text {-Development of poverty } \\
\text { alleviation programme. } \\
\text {-Sensitization about the } \\
\text { problem and awareness } \\
\text { programme. } \\
\text {-Increasing literacy rate. } \\
\text {-Vigorous inspections under } \\
\text { the act. }\end{array}$ \\
\hline
\end{tabular}

Source: Author

From the table above, the views of the Government Officers who are working in the field for abolition of child labour practices since long are presented. Out of the 12 officers of 10 districts interviewed, all the officers except the Asst labour Commissioner have stated that poverty and illiteracy are the main reasons of the child labour system. Two officers indicated that the lack of infrastructures and non-cooperation of the society and other departments are also among the reasons of child labour. All the officers stated that due to child labour system, the economic conditions of the society and the country remain underdeveloped and biological growth of the child labourer is hampered. In connection to all this, the remedies for elimination of the system, the concerned officers have opined that poverty alleviation programmes, motivation, awareness generation programmes and increasing literacy rate will eliminate child labour system.

\section{Opinion Survey of NGOs}

Although many NGOs are working in Western Odisha in this field, the author contacted two NGOs that agreed to give their opinion. Accordingly, a semi-structured questionnaire was constructed and these two NGOs were interviewed.

Table 11: Opinions of NGOs Officials Working In Western Odisha

\begin{tabular}{lllll}
\hline Name of the NGO & $\begin{array}{l}\text { Causes of child labour } \\
\text { problems }\end{array}$ & $\begin{array}{l}\text { Consequences of the } \\
\text { problems }\end{array}$ \\
NGO-1 & -Poverty & -No physical \& $\&$-Awareness. \\
\hline
\end{tabular}




\begin{tabular}{|c|c|c|c|}
\hline & $\begin{array}{l}\text {-Lack of basic needs. } \\
\text {-Mother's involvement in } \\
\text { the jobs. }\end{array}$ & $\begin{array}{l}\text { mental growth. } \\
\text {-Illiteracy. } \\
\text {-Disturbances } \\
\text { becoming in } \\
\text { citizens. }\end{array}$ & $\begin{array}{l}\text {-Implementation of the } \\
\text { laws properly in non- } \\
\text { hazardous conditions. } \\
\text {-All facilities to every } \\
\text { child for their growth \& } \\
\text { development. }\end{array}$ \\
\hline NGO-2 & $\begin{array}{l}\text {-Growth of populations } \\
\text {-Large family members. }\end{array}$ & $\begin{array}{l}\text {-Illiteracy. } \\
\text {-No physical growth, } \\
\text {-Child crimes } \\
\text {-Transfer of Bad } \\
\text { habits from adult } \\
\text { workers. }\end{array}$ & $\begin{array}{l}\text {-Proper investment of } \\
\text { Govt. aid. } \\
\text {-Family planning } \\
\text { should be encouraged } \\
\text { among villagers. } \\
\text {-Per head income } \\
\text { should be enhanced. }\end{array}$ \\
\hline
\end{tabular}

Source: Author

The table above indicates the views of two different NGOs of Western Odisha. Both the NGOs stated different reasons of child labour, e.g.; poverty, growth of population and large family size and mother's involvement in jobs. No physical and mental growth, illiteracy are considered the common consequences as opined by both the NGOs. Child crime is another consequence. The remedies as suggested by them are in awareness generation, family planning, improvement of income. These interventions according to them may reduce the extent of child labour practice in the state.

\section{Steps taken by the Government of Odisha}

In order to develop a coordination mechanism between the concerned states, Government of Odisha had initiated a discussion with Andhra Pradesh Government with facilitation from International Labour Organisation and the Ministry of Labour \& Employment, Government of India regarding the exploitative practices of bondage situations and migration of labour. The Government implement different poverty alleviation schemes for the migrant workers, but due to lack of awareness the workers cannot access those schemes which can help the target groups and their families to reduce their dependency on labour contractors, middleman and employers for advance and loan.

\section{Conclusion and Suggestion}

Child labour is more of a social problem. Therefore, in curbing it, society also has to take an initiative. Society includes everyone from the parents to the family to the employers and further to all the people. It is the duty of the society to see that the childhood of a child is not spent in the activities that are hazardous for his social, moral and physical development. Example of this can be felt by refraining from employing children or if anyone gets to know about such activity he must inform it to the society. So, it can be concluded that child labour is a social problem, for curbing it each one of us should take steps as only laws, policies, programs, NGO's cannot do anything. If we want to fulfil our dream of zero level child 
labour, each one of us has to be conscious and must do what one can do at its level. Implementation of child labour is lacking at the grass root level. Therefore, it is important to deal with the grass root level first. The government should take appropriate steps to reduce child labour. In Western Odisha, social and economic backwardness in terms of land ownership, caste and literacy level, apart from the family size, determine the degree of food insecurity. The greater intensity of this insecurity, the more the children would be forced to join work. Child Labour Rehabilitation Programme should be Pro-gender Pro-children and Pro- child labour. This problem should be considered in its totality and should not be viewed as a problem of the Labour Department. Convergence of other Government sponsored intervention programme related to fight against the root cause of child labour will help to a great extent to eliminate the problem.

\section{Conflict of Interest}

The author of the article declares no conflict of interest.

\section{Funding}

This research study was not funded by any institution. The author conducted the study on his own expenses.

\section{References}

De Haas, H., \& Rodríguez, F. (2010). Mobility and human development: introduction. Journal of Human Development and Capabilities, 11(2), 177-184.

Giri, V. (1958). Labour Problems in Indian industries, Mumbai: Asia Publishing House.

----- (2013). Child Labour: Issues \& Solutions. Chikiti Mahavidyalaya , Berhampur University

Ministry of Labour \& Employment, Government of India.(2006). Manual for Implementation of NCLP.

Ministry of Labour \& Employment, Government of India.(1986). The Child Labour (Prohibition and Regulation) Act.

Mishra, R. (2004). Problems of Child Labour in India. Commonwealth Publishers, New Delhi.

Nanda, S. K.. (2016). Give Me My Childhood. Publishing House Bhubaneswar. (2017). Labour Scenario in Odisha. Odisha Review, LXXIII(10). (2018). Child \& Labour Scenario In Odisha. Rquivo Brasileiro de Educação, 6(15), 76-102.

------- (2019). Let's Stop Child Labour-National Child Labour Project Scheme in India and Its Impact.

Orissa Government Report.(2009),Geography of Orissa, Orissa Reference Annual, Bhubaneswar.

Piesse, M. (2014). Factors Influencing Migration and Population Movements-Part 2 
Immigration and Population Movements in the Indian Ocean Region to 2025. Strategic Analysis Paper, Future Directions International.

Raj, N., \& Satpathy, A. K. (2002). Household food insecurity and child labour: Some evidence from rural Orissa. Coming to grips with rural child work. New Delhi: IHD Publishers.

Sinha, S. K. (1991). Child labour in Calcutta: a sociological study. Naya prokash

Sekar, H.(2015).The Child Labour(P\& R)Act,1986 and its Implementation, VVGNLI, Noida.

Census of Child Labour (2011), Retrieved from www.labour.gov.in-schemes-child labourcensus data Scheme of Child Labour (2012), Retrieved from www.labdirodisha.gov.in-child labour 